\title{
TERMIN „EUCHARISTIA” W PISMACH KLEMENSA ALEKSANDRYJSKIEGO
}

W niniejszym opracowaniu pragniemy zająć się wyłącznie rzeczownikiem $\varepsilon \cup ̉ \chi \alpha \rho \iota \sigma \tau l \propto$ i związana z nim problematykiz, a nie zagadnieniem eucharystil w ogóle. Mówiąc współcześnie o eucharystii mamy zazwyczaj na ứadze zarówno ofiarę eucharystyczną, mszę św., jak i pokarm eucharystyczny, Chrystusa obecnego pod postaciani chleba i wina. Na określenie tak rozumianej eucharystii Klemens Aleksandryjski używa róznych oznaczeń. Mówiąc np. o chlebie eucharystycznym, używa m.in. takich określeń jak: "chleb niebian"1, "mleko niebiańskie"2, "mleko miłó́c1" ${ }^{3}$, "pokarm niemowląt"4, "chleb Boży" 5 , "pokarm Pański"6, "winne

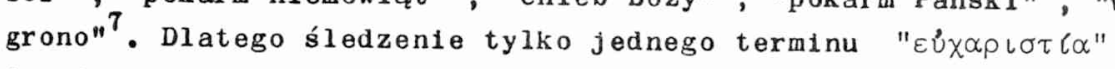

i związanego z nią kontekstu, nie wyczerpuje w żadnym wypadku całej tematyki. Z założenia więc niniejszy artykuł przyjmuje takie zawężenie problematyki. Gdyby nawet dodatkowo zająć się analiza miejsc,

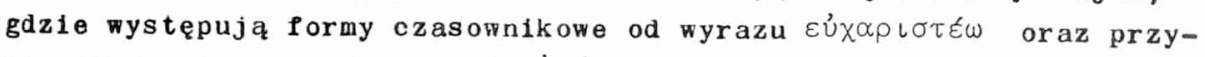

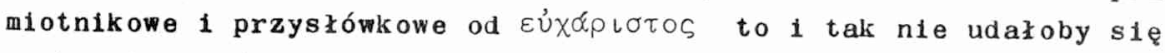
zrekonstruować całej klemensowej nauki o eucharystii. Autor bowiem nie podaje całościowego wykładu tej problematyki, cytowane zaś przez niego wypowiedzi sa najczęściej okazjonalne, w wielu wypadkach dyskusyjne 1 niejasne.

W opracowaniu niniejszym głównie będzie chodzić o ustalenie za-

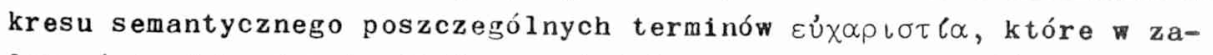
leżności od kontekstu bliższego 1 dalszego przyjmują dość nieoczekiwane znaczenia. Opierając się na tych badaniach zajmiemy się tez sprawami doktrynalnymi na tyle jednak tylko, na ile będa one wynikały

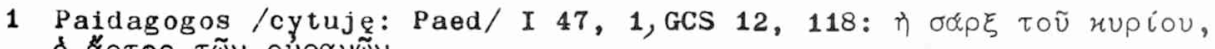

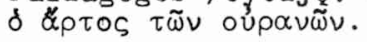

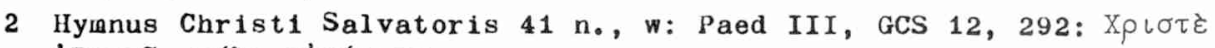

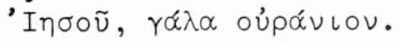

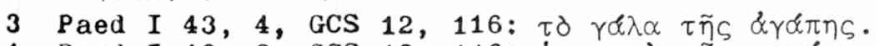

4 Paed I 43, 2, GCS 12, 116: ウे $\tau \rho \circ \varphi \eta े ~ \tau \tilde{\omega} \nu ~ \nu \eta \pi \ell \omega \nu$.

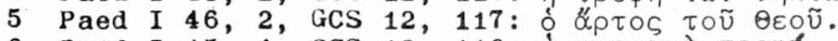

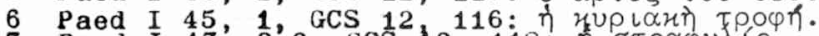

7 Paed I 47, $2-3, \operatorname{GCS} 12,16$ : 
bezpośrednio z badań semantycznych. Przy tym założeniu problematyka eucharystyczna wystąpi drugorzędnie, na pierwszy zaś plan wysun1e się kwestia modlitwy dziękczynnej i dziękczynienia w ogóle, jako stałej dyspozycji psychicznej, wyróżniającej chrześcijan dojrzzłych od tych, którzy nie osiągnęli jeszcze miłości doskonałej.

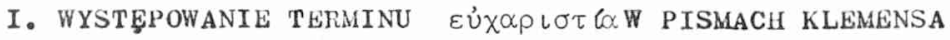

\begin{tabular}{|c|c|c|c|}
\hline$L \bullet p$. & Miejsce 8 & Forma & Znaczenie \\
\hline 1. & $\begin{array}{l}\text { Strom I } 5,1 \\
\operatorname{GCS} 52,5\end{array}$ & $\varepsilon \dot{u} \chi \alpha \rho \iota \sigma \tau \zeta \alpha \nu$ & $\begin{array}{l}\text { pokarm eucharystycz- } \\
\text { ny - komunia św. } \\
\text { /"rozdawanie eucha- } \\
\text { rystii"/ }\end{array}$ \\
\hline 2. & $\begin{array}{l}\text { Strom III } 2,3 \\
\text { GCS } 52,196\end{array}$ & 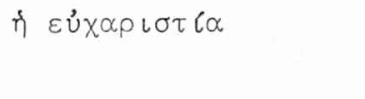 & modlitwa dziękczynna \\
\hline 3. & $\begin{array}{l}\text { Strom III } 85,1, \\
\text { GCS } 52,235\end{array}$ & $\begin{array}{l}\mu \varepsilon \tau^{\prime} \varepsilon \dot{U} \chi \alpha \rho\llcorner\sigma \tau \ell \alpha \varsigma \\
1 \operatorname{Tm} 4, \mathbf{1}-3\end{array}$ & $\begin{array}{l}\text { "z wdzięcznością" } \\
\text { /dziękczynieniem/ }\end{array}$ \\
\hline 4. & $\begin{array}{l}\text { Strom III } 85,1, \\
\text { GCS } 52,235\end{array}$ & $\begin{array}{l}\mu \varepsilon \tau^{\prime} \varepsilon \dot{u} \chi \alpha \rho\llcorner\sigma \tau l \alpha S \\
1 \text { Tm 4, } 1-3\end{array}$ & $\begin{array}{l}\text { "z wdzięcznością" } \\
\text { /dziękczynieniem/ }\end{array}$ \\
\hline 5. & $\begin{array}{l}\text { Strom III } 85,2, \\
\text { GCS } 52,235\end{array}$ & $\begin{array}{l}\mu \varepsilon \tau^{\prime} \varepsilon \cup ่ \chi \chi \rho\llcorner\sigma \tau l \alpha \zeta \\
1 \operatorname{Tm} 4,4 ; \operatorname{Rz~14,6}\end{array}$ & $\begin{array}{l}\text { "z wdzięcznością" } \\
\text { /dziękczynieniem/ }\end{array}$ \\
\hline 6. & $\begin{array}{l}\text { Strom III } 85,2, \\
\text { GCS } 52,235\end{array}$ & $\begin{array}{l}\mu \varepsilon \tau{ }^{\prime} \varepsilon \cup{ }^{\prime} \chi \propto \rho \iota \sigma \tau l \alpha \varsigma \\
1 \operatorname{Tm} 4,4 ; K_{\mathrm{Z}} 14,6\end{array}$ & $\begin{array}{l}\text { "z wdzięcznością" } \\
\text { /dziękczynieniem/ }\end{array}$ \\
\hline 7 . & $\begin{array}{l}\text { Strom III } 95,3 \\
\text { GCS } 52,240\end{array}$ & $\begin{array}{l}\mu \varepsilon \tau^{\prime} \varepsilon \dot{U} \chi \alpha \rho \downarrow \sigma \tau l \alpha S \\
1 \operatorname{Tm} 4,4\end{array}$ & $\begin{array}{l}\text { "z wdzięcznośc1ą" } \\
\text { /dziękczynieniem/ }\end{array}$ \\
\hline 8. & $\begin{array}{l}\text { Stroin IV } 161,3, \\
\text { GCS } 52,320\end{array}$ & $\varepsilon \cup \dot{\chi} \alpha \rho\llcorner\sigma \tau l \alpha \zeta$ & $\begin{array}{l}\text { eucharystia jako } \\
\text { ofiara /na wzór ofia- } \\
\text { ry Melchizedeka/ }\end{array}$ \\
\hline 9. & $\begin{array}{l}\text { Strom V } 61,4 \\
\text { GCS } 52,367\end{array}$ & $\begin{array}{l}\text { Év } \varepsilon \cup ̉ x \alpha \rho\llcorner\sigma \tau\lceil\alpha \\
\text { Kol } 4,2\end{array}$ & modlitwa dziękczynna \\
\hline . & $\begin{array}{l}\text { Strom V 61, 5, } \\
\text { GCS } 52,367\end{array}$ & $\hat{\eta} \varepsilon \cup \dot{x} \alpha \rho\llcorner\sigma \tau \iota \alpha$ & modlitwa dziękczynna \\
\hline
\end{tabular}

8 Termin $\varepsilon \dot{x} \alpha \rho\llcorner\sigma \tau \ell \alpha$ występuje w Stromateis /cytuję: Strom/ oraz w Paed. 


\begin{tabular}{|c|c|c|c|}
\hline$L \bullet p$. & Miejsce & Forma & Znaczenie \\
\hline 11. & $\begin{array}{l}\text { Strom VII } 62,1, \\
\operatorname{GCS} 17,44\end{array}$ & 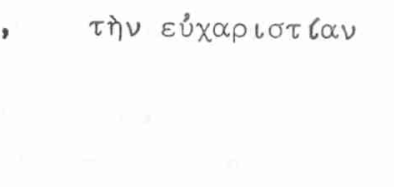 & $\begin{array}{l}\text { postawa dziękczynienia } \\
\text { /towarzysząca korzysta- } \\
\text { niu z dóbr przez Boga } \\
\text { stworzonych/ }\end{array}$ \\
\hline 12. & $\begin{array}{l}\text { Strom VII } 79,2, \\
\text { GCS } 17,56\end{array}$ & $\varepsilon \cup \dot{\chi} \chi \alpha \rho\llcorner\sigma \tau l \alpha$ & $\begin{array}{l}\text { postawa dziękczynienia } \\
/ \text { jako stała dyspozycja/ }\end{array}$ \\
\hline 13. & $\begin{array}{l}\text { Paed I 22, 2, } \\
\text { GCS 12, } 103\end{array}$ & $\varepsilon \cup \dot{x} \alpha \rho \iota \sigma \tau \ell \alpha$ & $\begin{array}{l}\text { modlitwa dziękczynna } \\
\text { /za tych, co wytrwali } \\
\text { w Kościele/ }\end{array}$ \\
\hline 14. & $\begin{array}{l}\text { Paed I 22, } 3 \\
\text { GCS } 12,103\end{array}$ & $\tau \eta े \nu ~ \varepsilon u ̉ \chi \propto \rho\llcorner\sigma \tau \zeta \alpha \nu$ & $\begin{array}{l}\text { postawa dziękczynienia } \\
\text { /jako element składowy } \\
\text { Kościoła/ }\end{array}$ \\
\hline 15. & $\begin{array}{l}\text { Paed II 10, } 3 \\
\text { GCS 12, 161 }\end{array}$ & 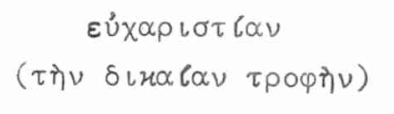 & $\begin{array}{l}\text { pokarm eucharystyczny } \\
\text { /pokarm prawdziwy/ }\end{array}$ \\
\hline 16. & $\begin{array}{l}\text { Paed II } 20,1 \\
\text { GCS 12, } 168\end{array}$ & $\varepsilon \mho \chi \alpha \rho\llcorner\sigma \tau \ell \alpha$ & $\begin{array}{l}\text { pokarm eucharystyczny } \\
\text { /Krew Chrystusa/ }\end{array}$ \\
\hline 17 . & $\begin{array}{l}\text { Paed II } 43,1, \\
\text { GCS 12, } 183\end{array}$ & $\delta \iota^{\prime} \varepsilon u ́ \chi \alpha \rho \iota \sigma \tau \iota \alpha_{S}$ & $\begin{array}{l}\text { modlitwa dziękczynna } \\
\text { /obok psalmodil/ }\end{array}$ \\
\hline 18. & $\begin{array}{l}\text { Paed II } 50,1 \\
\text { GCS 12, } 187\end{array}$ & $\begin{array}{l}\varepsilon \cup \dot{u} \chi \alpha \rho\llcorner\sigma \tau \ell \alpha \\
\operatorname{Ee} 5,4\end{array}$ & $\begin{array}{l}\text { miłe względem bliźnich } \\
\text { usposcbienie }\end{array}$ \\
\hline 19. & $\begin{array}{l}\text { Paed II 96, 2, } \\
\text { GCS 12, } 215\end{array}$ & 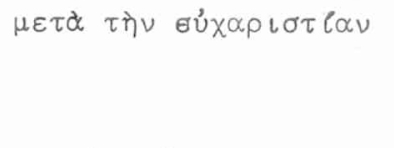 & $\begin{array}{l}\text { modlitwa dziękczynna za } \\
\text { otrzymane dobra /przed } \\
\text { snem/ }\end{array}$ \\
\hline 20. & $\begin{array}{l}\text { Paed III 95, 4, } \\
\text { GCS 12, } 288\end{array}$ & 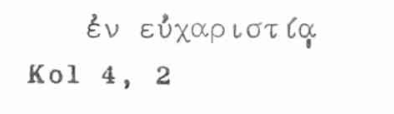 & modlitwa dziękczynna \\
\hline 21. & $\begin{array}{l}\text { Paed III 101,3, } \\
\text { GCS 12, } 291\end{array}$ & $\varepsilon u ̛ \chi \alpha \rho \iota \sigma \tau l \alpha S \quad \delta \iota x \alpha l \alpha_{S}$ & $\begin{array}{l}\text { modlitwy dziękczynne } \\
\text { /należne Bogu/ }\end{array}$ \\
\hline
\end{tabular}

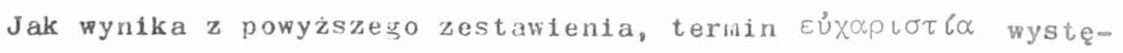
puje w pismach Klemensa 21 razy, w tyw w "Stromatach" 12 razy oraz w "Pedagogu" 9 razy. Generalnte można mówić o dwóch podstawowych gru- 
pach znaczeniowych.

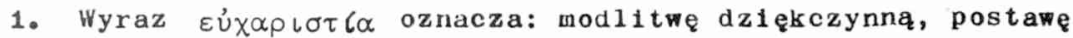
dziękczynienia, wdzięcznośc1 względem Boga; miłe względem bliźnich usposobienie. W tym znaczeniu termin ten występuje u Klemensa az 17 razy;

2. Wyraz $\varepsilon u ́ x \alpha \rho \iota \sigma \tau l \alpha$ oznacza pokarm eucharystyczny, tj. Ciało 1 Krew Chrystusa oraz ofiare Nowego Testamentu, której Pigurą jest ofiara Melchizedeka. W tym znaczeniu termin ten wystepuje u Klemensa tylko 4 razy.

W sumie na 21 określé́ $\varepsilon u ́ \chi \alpha \rho \iota \sigma \tau \ell \alpha$ tylko cztery dotyczą wprost eucharystii, co stanowi zaledwie 19\% badanych terminów. Tak więc, omawiany rzeczownik w pierwszym rzędzie bywa użyany przez Klemensa na określenie modlitwy dziękczynnej, wdzięcznośc1 1 postawy dziękczynnej jako stałej dyspozycji psychicznej. W tym względzie Klemens wyraźnie nawiązuje do tradycji nowotestamentalnej, gdzie termin $\varepsilon \dot{U}-$ $\chi \alpha \rho \iota \sigma \tau l \alpha$ był użyman, w tym włánie znaczeniu, bardzo często. Wielce wymowny jest fakt, ze aź ośmiokrotnle występuje u Klemensa wyraz $\varepsilon \dot{\chi} \chi \alpha \rho \iota \sigma \tau l \alpha$ w cytatach z listów Pawłowych, gdzie idea dziękczynienia jest tak zywa 1 wszechobecna ${ }^{9}$.

\section{II. 'EYXAPIETIA - OFIARA NOIEGO PRZYMIERZA, POKARM} EUCHARYSTYCZNY

a/ Euc h a r y s t i a o f i a r a $N$ o w e g o p r z y $m 1$ e $\mathrm{r}$ a. W IV Stromacie zamieszczona jest wypowiedz Klemensa, która posiada fundamentalne znaczenie dla ustalenia jego poglądów o eucharysti:

"Przez Salem rozumie się "pokój". Nasz Zbawiciel nazywany jest Królem Salemu; o tym mówi Mojzesz: Melch1zedek,

9 Por. Słownlk Teologii Biblijnej, red. X. Léon-Dufour, tłum. K. Romantuk, Warszawa 1982, 259. 
król Salemu, kapłan Boga Najwyższego, który daje wino 1 chleb, uświęcony pokarm, co stanowi prawzór dla eucharyst1i ( $\varepsilon l_{S} \tau u \pi \circ \nu \varepsilon u ́ \chi \alpha \rho \iota \sigma \tau \ell_{\zeta}$ )"10.

Wskazanie na ofiare Melchizedeka jako na typ eucharystil, zdaje sie implicite zawierać twierdzenie o tym, ze eucharystia jest orfara. Wnioskowanie to próbowano osłabić, wskazując na wypowiedzi Klemensa, w których wyraźnie odrzuca potrzebę ofiar ${ }^{11}$. I tak, w VII Stromacie, deklaruje Klemens swoje poglądy wej materii dość jednoznacznie:

"Z tej przyczyny słusznie oflar nie składamy Bogu, który przeciez niczego sam nie potrzebuje, a wszystkiego wszystkim uzycza, ale/przez nie/ siawimy Tego, który sam siebie złoz̀y na ofiarę oraz sami siebie składamy w oflerze ku uzyskaniu coraz większego braku potrzeb 1 coraz większej bezafektywnoścín12.

Sprzeczność zostaje rozwi zzana po rozwazenlu kontekstu powyższej wypowiedzi. Okazuje sie bowiem, ze owszem Klemens odrzucał potrzebę ofiar krwawych, które praktykowane były pogaństwie. Odnośnie do eucharystil akcentuje w Innym miejscu potrzebę, by była sprawowana

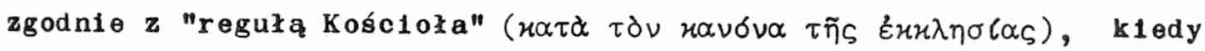
potępia praktyki akwarian, którzy do eucharystii używali tylko samej wody, z wykluczenlem wina ${ }^{13}$.

W nauczaniu Klemensa pojawia się równiez pojęcie "ofiary Kó́-

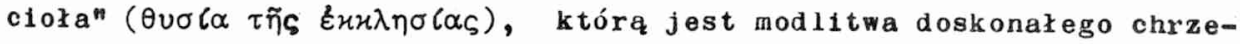
ścijanina /gnostyka/:

"A kiedy my powiadamy, że prawdziwie świętym ołtarzem jest dusza sprawiedliwa 1 że wznoszącym się z tego oftarza dymen of arnym jest zboźna modlitwa, to nie chcą nam lerzycin14.

10 Strom IV 161, 3, GCS 52, 319 n. Cytuję według zawartego jeszcze w rękopisie tłumaczenia J. Pliszczý́skiej.

11 Por. J. Quasten, Patrologia, I, Casale Monferrato 1967, 307.

12 Strom VII 14, 5, GCS 17, 11.

13 Strom I 96, 1-2, GCS 52, 61-62: "Przy tym słów chleb 1 woda" uzywa tu Logos zupełnie wyraźnie nie wosunku do czego innego, jak do herezji, które używaja chleba 1 wody do oflarowania ( $\varepsilon$ $\chi \propto \rho\llcorner\sigma \tau о \tilde{\sigma}(\nu)$ niezgodnie z reguła Kośloła"; por.Prz 9, 15.

14 Strom VII $32,4-5$, GCS $17,24$. 
Pojecle modlitwy jako "oplary Kościoła" Punkcjonuje paralelnie 1 w niczym nie przeszkadza, by przyjać, ze Klemens uznawał ofiarniczy charakter eucharyst11.

b/ E "Podagoga" znajdujemy tekst dotyczący eucharysti1, który ze względu na swą niezwykłą zawartość, bardzo często cytowany jest w podręcznikach patrologi1 15 :

\begin{abstract}
"Dwojaka jest Krew Pana: jedna cielesna, dzięki której zostaliśmy wybawieni od zguby, druga duchowa, dzięki której zostalí́my namaszczeni. A pić Krew Jezusa oznacza uczestniczyć w niesmiertelności Pana. Duch jest siła Logosu, jak krew jest siła ciała. Analogicznie więc miesza się wino z woda, jak duch kączy się z człowiekiem; pierwsza mieszanka, wody 1 wina, syci nas ku wierze; druga zaś, ducha, prowadz1 nas do nieśmiertelności; połączenis ( $\mu \rho \tilde{\sigma} \sigma \varsigma$ ) natomiast

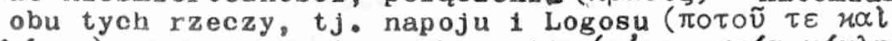

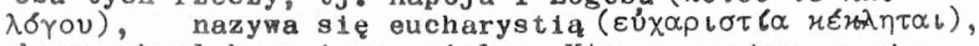
darem chwalebnym 1 wspaniałym. Kto go spozywa z warą, zostaje uświęcony na ciele 1 na duszy"16.
\end{abstract}

W powyższym tekście mówi klemens o napoju eucharystycznym, którym jest Krew Chrystusa. Czyni przy tym wyraźne rozró zniente między krwia cielesną Chrystusa, przez która dokonało się dzieło zbavie= nia 1 Krwla eucharystyczną, która jest napojem życia wiecznego. Napój ten powstaje przez połączenie wody 1 wina oraz Logosu, tj. Chrystusa. W tym sformuzowaniu zawarta jest teza o prawdziwej obecności Chrystusa w Krwi eucharystycznej oraz wyraźne stwierdzenie, ze materia eucharystil jest woda 1 wino. Mówi też o owocach euchsryst11, którymi gą uświęcenie cielesne 1 duchowe oraz udział wieśmiertelności Chrystusa.

W innym miejscu czyni Klemens wzmiankę, dość ogólną, o rozdzielaniu eucharystil, które porównuje do przekazywania kerygmatu pisemnego ${ }^{17}$. W I Stromacie tak pisze na ten temat:

15 Por. B. Altaner, Patrolog $1 a^{6}$, Casale Monferrato 1968, 199; J. Quasten, dz. cyt., 308; S. Pleszczoch, Patrologia, Poznań 1964, 94.

16 Paed II $19,4-20,1, \operatorname{GCS} 12,167 \mathrm{n}$.

17 Na temat kerygmatu pisemnego zob。: F. Draczkowsk1, Kerygmat pi- 


\begin{abstract}
"Ci dwaj muszą się nawzajen kontrolować: jeden - czy godzien jest mówić i utrwalać to dla potomności na piśmie, drugi zaś - czy jest w prawie słuchać to i czytać. Podobnie rzecz się ma z rozdawaniem eucharystii ( $\varepsilon \cup x \propto \rho\llcorner\sigma \tau \ell \alpha \nu)$. Niektórzy ją dzielą, jak zwyczajowo przyjęte, każdemu z wiernych pozocitawiajįc do dyspozycji wziąć swą część (
\end{abstract}

Wyrażenia nówiąc o "dzieleniu" i "braniu swej części" zdają się wskazywać, że autor miał na myślı Chleb eucharystyczny. W pismach Klemensa nie brak wypowiedzi, w których ałcentuje się potrzebę pożywania Ciała i picia Krwi Pańskiej, poprzez które winnismy porzucá́ starego człowieka, "Zbaviciela zaś przechowywać w sercu"19.

\title{
III. 'EYXAPIETIA - STALA POSTAWA DZIEKCZYNIENIA
}

W wykładzie Klemensa Aleksandryjskiego termin $\varepsilon \cup ̉ x \alpha p \iota \sigma \tau \iota \alpha$ najwięcej, bo aż 8 razy, został użyty w znaczeniu "postawa dziękczynie-

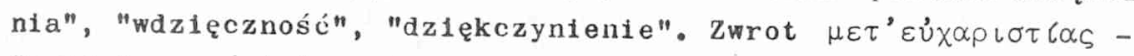
"z wdzięcznością" występuje aż 6 razy. Fakt ten nie jest rzeczą przypadku. Naleźy bowiem uświadomić sobie, że w czasach Klemensa poważnym problemem były sekty heterodoksyjne o charakterze enkratyckim, żądające stosowania w życiu rygorystycznie rozumianej ascezy. W zakresie praktyki życia codziennego sekty te żądały wyeliminowania spożywania pokarmów mięsnych i picia wina 20. Przyjmowały tez niezwykle radykalną postawę względem małżeństwa i rodziny, zakazując wstępowania w zwiazki małżeńskie, i - co za tym idzie - płodzenia potomstwa. Twierdzłły, że pożycie seksualne i narodziny są przeklęte 1 zabronione przez nowe prawo, które przyniósł Chrystus ${ }^{21}$. Wśród głómnych przedstawicieli tych sekt wylicza Kleınens Marcjonistów, Tacjanitów

semny w teorii $i$ praktyce Klenensa Aleksandryjskiego, KTK 26/1979 z. $6,21-43$.

18 Strom I 5, 1, GCS $52,5$.

19 Paed I $42,3-43,1, \operatorname{GCS} 12,115$.

20 Strom III $85,1-2$, GCS $52,235$.

21 Strom III 49,1 , GCS 52,$218 ; 80,3$, GCS 52,$232 ; 91,1$, GCS 52,238 ; 102,3 , GCS 52, 243: por. F. Drączkowski, Swiętośćmałżústwa i rodziny według Klemensa Aleksandryjskiego,Voxp 5/1985/z.8-9,96-110. 
1 zwolenników Kasjana 22.

Klemens stanowczo przeciwstawiał się tym tendencjom, piętnując 1 ch bluźnierczy charakter, uwłaczający mądrośc1 1 dobroci Boga. Podkreślał, ze wszystkie rzeczy stworzone przez Boga sa dobre. Człowiek winien z nich korzystać, zachowując równocześnie stałą postawę dziękczynienia za wszystkie dary Boze. Fakt istnienia herezji o takich tendencjach wpłynął stymulująco na Klemensa, skłaniając go do wyeksponowania postawy dziękczynienia jako wyrazu uwielbienia 1 czci dla Stwórcy. Nawiazuje przy tym do wypowiedzi św. Pawła, który spotykał się z podobnymi problemami. Postawa wdzięczności Bogu winna stale towarzyszyć zarówno tym, którzy spożywaja mięso 1 pija wino, jak 1 tym, którzy tego nie czyniaj tym, którzy żyą w związkach małzeńskich, jak 1 tym, którzy zachowuja celibat. Znamienna w tym zakresie jest następująca wypowiedź:

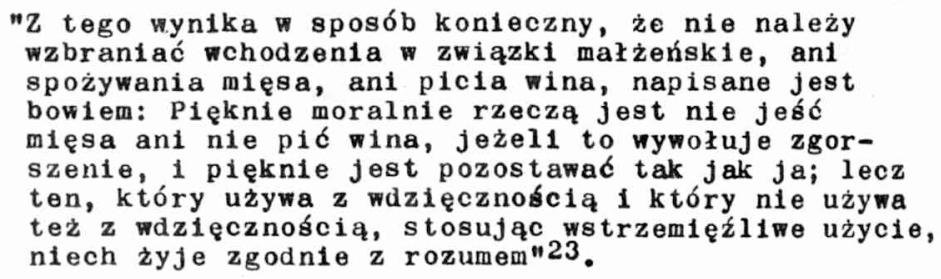

Co więcej, Klemens idzie jeszcze dalej, mianowicle, broniąc postawy korzystania z dóbr stworzonych, uważa ja nawet za lepszą od postawy wyrzeczen1a. Jego bowiem zdaniem przyjaciel Boga, czyli gnostyk,

\footnotetext{
"robiąc użytek z rzeczy ziemskich nie tylko okazuje tym wdzięczność 1 podziw dla aktu stworzenia, ale przez waściwe $1 \mathrm{ch}$ zastosowanie zyskuje uznanien24.
}

22 Na temat tych sekt zob. F. Drączkowski, Niektóre tendencje 1 zasady pierwszych wspólnot heterodoksyjnych na podstawie Stromatów Kiemensa Aleksandryjskiego RTK 23/1976/ z. 4, 70-75.

23 Strom III 85,2 , GCS 25, 235; por. $1 \operatorname{Tm} 4,4$; Rz 14, 6; por. Strom III 85,1, GCS 52,$235 ; 86,1$, GCS $52,235$.

24 Strom III 83, 3, GCS 52, 234. 
Pochwala takiej postawy nie oznacza bynajmniej aprobaty hedonizmu w życiu chrześcijańskim. Wrecz przeciwnie, korzystaniu, zdaniem klemensa, winien towarzyszyé stały dystans wobec rzeczy materialnych 1 ciagła gotowość do ich wyrzeczenia się, gdyby zaszła taka potrzeba. Przyjaciela Boga winna cechować beznamiętność. Nawiązując do słów św. Pawła, pisze:

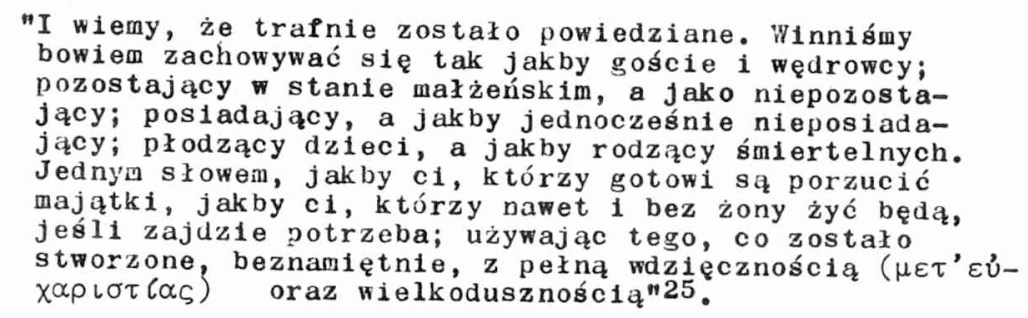

Czynnikani pomocniczymi w zakresie doboru jakości 1 ilości dóbr stworzonych, winny być - zdaniem Klemensa - rozum oraz właściwa postawa moralna, daleka od płytkiego hedonizmu. Dlatego tez doskonały chrześcijanin, czyll "gnostyk korzysta z dóbr stworzonych, ale, llekroć rozum wybierze oraz ile wybierze; pełen wdzięcznośc1 ( $\varepsilon \cup ́ x \alpha \rho\llcorner\sigma \tau(\alpha \nu)$ dla Stwórcy; oraz okazuje się panem nad przyjemnością ich użycian ${ }^{26}$.

Postawa dziokczynienia winna, zdaniem Klemensa, towarzyszyć nie tylko korzystaniu z dóbr stworzonych, ale winna być stałą dyspozycją wewnętrzną, obejmującą serce 1 umysł chrześcijanina, obecną w każdej sytuacji życiowej, nie wyłączając momentów krzyźa 1 cierpienia. Przykład takiej dyspozycji dali apostołowie, którzy nawet podczas mąk 1 cierpień Pizycznych trwali w dziękczynientu, wypływającym z wiary heroicznej:

"Czy nie wykazali w sposób jak najbardziej widoczny swej wiary w nadzieje pośmiertna, gdy w czasie największych tortur wyraźali wdzięczność Bogu? Niezłomną, myślę, wiarę poşadali. A tej wierze towarzyszyły wierne czyny" 27 . 
Charakterystykę przyjaciela Boga, żyjącego w radości 1 nieustannym dzięczynieniu, zawarł Klemens w następującym opisie:

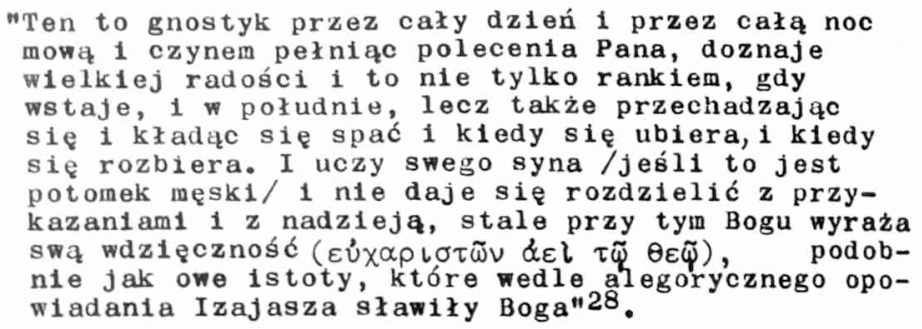

\section{IV. 'EYXAPIETIA - MODLITWA DZIEKCZYNNA}

Termin $\varepsilon \cup ̉ x \propto \rho \iota \sigma \tau \zeta \alpha$ w pismach Klemensa byพa używany nie tylko na określenie "postawy dziękczynienia" 1 "wdzięczności" względem Boga, ale również na oznaczenie modlitwy dziękczynnej. Autor nasz bowiem wyraźnie stwierdza, że $\varepsilon \cup ́ x \alpha \rho \iota \sigma \tau l \alpha$ jest "rodzajem modlitwy"

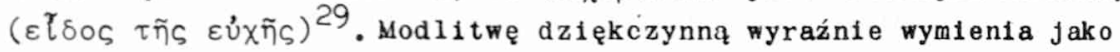
coś odrębnego, gdy zachęca, by naszą przyjaźn względen Boga umac-

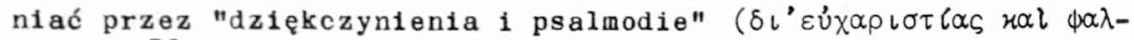
$\mu \psi \delta(\alpha \varsigma)$ 30. Cytuje teź nypowiedź Izydora, który stwierdza, ze ten rodzaj modlitwy, jakim jest modlitwa dziękczynna ( $\varepsilon \dot{x} \chi \alpha \rho \sigma \tau(\alpha)$,

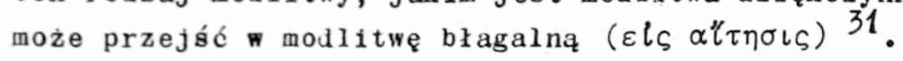

Określa też, kiedy należy kierować do Boga tego rodzaju modlitwę. Podaje m.in., że modlitwę dziękczynną należy odmawiać po posiłku oraz przed udanien się na spoczynek ${ }^{32}$. Oznacza teź przedmiot modlitwy dziękezynnej. Najpierw stwierdza ogólnie, że winntśmy dziękować za całokształt dóbr materialnych 1 duchowych. Nawiązując do słów św. Pawła: "trwajcie przy modlitwie w czujności, składając dziękczynienie" wyjaśnia, że "dziękczyniente ( $\varepsilon \dot{\chi} \propto \propto \rho \iota \sigma(\alpha)$ dotyczy nie tylko duszy 1 dóbr duchowych, lecz równlez ciała 1 dóbr

28 Strom VII 80,4, GSC $17,57$.

29 Strom VII 79,2 , GSC $17,56$.

30 Paed II 43,1, GCS $12,183$.

31 Strom III 2, 3, GCS 52, 196.

32 Paed II 96,1, GCS 12, 215; por. Plutarchus, Moralia 654 f. 
duchowych, leez również ciała i dóbr cielesnych" ${ }^{33}$. Dziękować winniśmy, zdaniem Klemensa, nie tylko za wszystkie dobra otrzymane od Boga, ale rómniez za całokształt historii naszego życia, tj. za wydarzenia minione, za obecne 1 za te, które nastąpią, innymi słowy mówiąc - "za to, co już minęło, za to, co się dzieje, za to, co jeszcze ma nastąplé, a co dzięki wierze juž jest niejako obecnen34.

\section{v. 'EYXAPIETIA - ELEMENT SKLADOWY KOŚSIOLA}

W I księdze "Pedagoga" zamieszczona jest ważna wypowiedź doty-

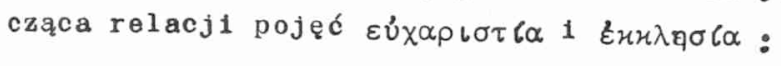

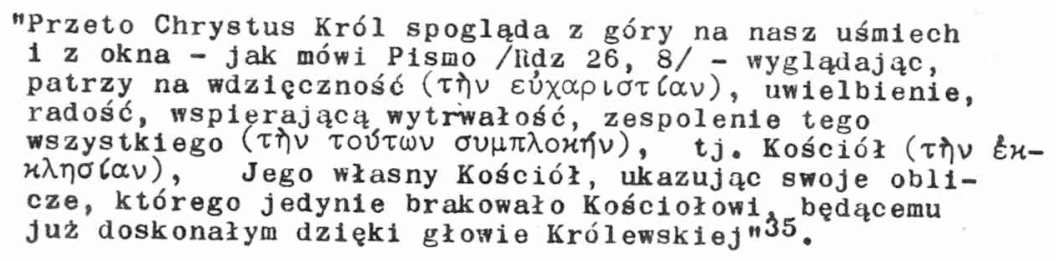

Dla naszej problematyki najważniejsze jest stwierdzenie,zawarte w powyższym tekście, że Kościół jest zespoleniem wielu różnych wartości, wśród których wymieniona jest $\varepsilon \dot{\chi} \alpha \rho \iota \sigma \tau \ell \alpha$. Ze względu na ogólny charakter powyższej wypowiedzi termin $\varepsilon \dot{x} \chi \rho \iota \sigma \tau l \alpha$ może być rozumiany bardzo szeroko, tj. nie tylko jako "wdzięczność", ale również jako "dziękczynienie", "postawa dziękczynna", "modlitwa dziękczynna". Teza powyższa, w kontekście tego wszystkiego, co wyżej zostało powiedziane na temat rzeczownika $\varepsilon u ́ x \alpha \rho \iota \sigma \tau \iota \alpha$, wydaje się dość jasna 1 konsekwentna. Kościół bowiem, według Klemensa, składa się z Głowy 1 Ciała stanowiąc wspólnotę życia Chrystusa, Boga w Trójcy jedynego 1 ludu Bożego ${ }^{36}$. Jeśli każly wierny rozwija w sobie postawę dzlękczynienia 1 realizujo program wyżej nakreślony, trwając stale w dziękczynieniu, to moźna powiedzieć, ze tak jak Kościół jest zespoleniem wiernych w Chrystusie, tak teź jest zespoleniem "wdzięczności" 1 "dziękczynienia", które jest obecne w życiu każdego członka Ludu Bożego. Zatem 
na 1 le Kościół jest zespolenten wiernych, na tyle też jest zespoleniem "dziękczynienia"。

Powyższą interpretację można by też rozszerzyć o aspekt eucharystyczny. Termin $\varepsilon u ́ x \alpha \rho \iota \sigma \tau l \alpha o z n a c z a$ przeciéz nie tylko "dziękczynienie", ale również Ciało 1 Krew Pańska, tj. pokarm eucharystyczny, którym się karmią wszyscy wierni oraz ofịarę Nowego Przymierza, w której uczestnicza wszyscy członkowie ludu Bozego. Kó́ciól zatem byłby zespoleniem wiernych 1 Chrystusa eucharystycznego, obecnego w każdym z nich.

Termin $\varepsilon \cup ́ x \propto \rho \iota \sigma \tau \zeta \alpha$ przyjmuje w pismach Klemensa jeszcze jedno dość zaskakujące znaczenie, dotyczące postawy wiernych względem sieb1e. Klemens, mając na uwadze sferę zycia codziennego, nawołuje za 8́. Pawłen do właściwego, budującego zachowania w mowie. Cytuje następujące słowa z Listu do Efezjan:

"Niech nie wychodzi z waszych ust zadna mowa szkodliwa, lecz tylko budująca /.../. o nierządzie zaś 1 wszelkiej nieczystości albo chciwości niechaj nawet mowy nie będzie wśród was, jak przysto1 şwiętym. Raczę winno być wazięczne usposobienie ( $\varepsilon \dot{x} \chi \rho\llcorner\sigma \tau \iota \alpha) " 37$.

Cały kontekst powyższej wypowiedzi zdaje sie wskazywać na to, ze Klemens przez wyraz $\varepsilon \cup ́ x \propto \rho\llcorner\sigma \tau\lceil\alpha$ rozumiał "miłe względem blı́nıch usposobienie" 38 . Zatem $\varepsilon u ́ x \alpha \rho \iota \sigma \tau l \alpha, j$ ako postawa wdzięcznośc1 względem Boga, w relacjach międzyludzkich winna przejawiać się jako właściwie rozumıana, pełna wdzlęku kurtuazja. Ten czynnik znajduje pełne dowartó́ciowanie w doktrynie Klemensa, który wielokrotnie eksponuje potrzebę zdrowego savoir-vivre, czego liczne śwadectwa znajdujemy w II 1 III księdze "Pedagoga". Wszystko zdaje sie wskazywać na to,

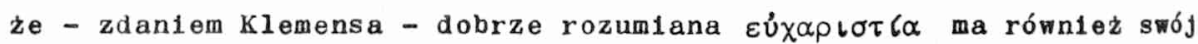
wymiar eklezjalny w pionie formowania właścimych obyczajów.

go, Lublin 1983, 129 .

37 Paed II 50,1, GCS 12,187 ; por. Ef 4, 29; 5, 4.

38 Listy więzienne świętego Pawła, oprac. A. Jankowski, Poznań 1962, 469: "Jednakże już w starożytności chrześcijanskiej miało zwolen-

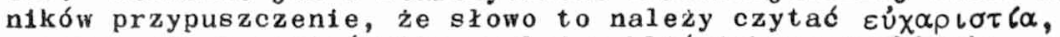
a przez nie rozumieć miłe wgględem bliźnich usposobienie, ánalogicznie do zaleceń Kol 4, 6 /Klemens Aleksandryjski, Orygenes, Hieronim, Kajetan/. Sens ten - trzeba przyznać - bardziej od "dziękczynienia" harmonizowałby z blizszym kontekstem". 
W podsumowaniu należy zaznaczyé, że termin $\varepsilon u ́ x \alpha \rho \iota \sigma \tau l \alpha w$ pismach Klemensa przyjmuje o wiele szerszy zakres znaczeniowy, niz to ma miejsce w dzisiejszej teologii, gdzie wyraz ten bywa prawie wyłącznie używany na określenie ofiary i pokarmu eucharystycznego. Co prawda 1 w tych znaczeniach termin ten występuje u Klemensa, lecz w proporcji do całości problematyki, zajmuje zaledwie jedną piątą część. Na temat eucharystii jako ofiary Nowego Przymierza znajdujemy zaledwie jednį, dość lakoniczną rzmiankę, o tym że ofiara Melchizedeka jest typen eucharystii. Klemens przypomina też, że materią ofiary eucharystycznej jest wino $i$ woda, a to z racji poleaiki z akwarianami, którzy do eucharystil uźywali wyłącznie wody. Nieco więcej uwagi poświęcił klemens sprawie pokarmu eucharystycznego. Poucza o prawdziwości obecności Chrystusa pod postaciami chlaba $i$ wina. Przypomina o potrzebie przyjmowania Ciała 1 Krwi Paŕskiej, poprzez które realizuje się nasze uświęcenie 1 zagwarantowany jest udział w nieśmiertelności Chrystusa.

Nawiązując do tradycji nowotestamentalnej Klemens w pierwszym

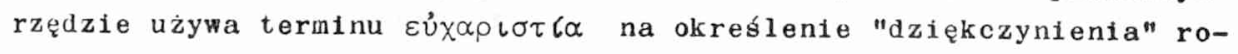
zumianego jako stałej postawy wdzięczności względem Boga. Polemizując z sektami enkratyckimi akcentuje, że wszystko, co Bóg stworzył, jest dobre. Dlatego też człowiek winien korzystać ze wszystkich dóbr zachowując stała postawę dziękczynienia. Podobnie wyraża się o poźyciu małżeńskim, które sekty skrajnie ascetyczne zdecydowa-

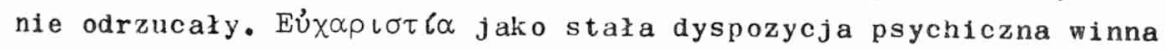
wyrażać się w dziękczynieniu za wszystkie dobra duchowe $i$ materialne, za wszystkie wydarzenia całego życia. Dziękować Bogu należy o każdej porze dnia 1 nocy, w każdej sytuacji, nie wyłączając chwili krzyża 1 cierpienia. Owocen takiej postawy jest radość. Ideał tak rozumianej postawy dzięceznnej realizuje w pełni gnostyk, tj. doskonały chrześcijanin, przyjaciei Boga.

Termin $\varepsilon u ̉ x \rho \iota \sigma \tau \swarrow \alpha$ występuje też u Klemensa w znaczeniu modlitwy dziękczynnej, określanej wyraźnie przez niego jako osobny "rodzaj modlitwy". Autur nasz określa przedmiot 1 okolicznośc1, w jakich nalezy odmawiać modlitwy dziękczynne. Dość nieoczekiwanie

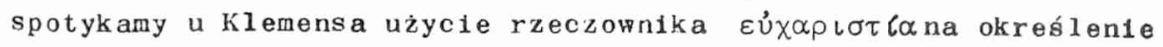
"miłego względen bliźnich usposobienia". Syntetycznym ujęciem omawianej problematyki jest stwierdzenie, że $\varepsilon u ́ x \propto \rho \iota \sigma \tau \complement \propto$ jest elementem składowym Kościoła. W wizji Klemensa 1dentyfikują się: Chrystus 
eucharystyczny obecny w sercach wszystkich wiernych z Chrystusem Głową Mistyeznego Ciała; Kościół jako zespolenie wiernych, którzy żyją dziękczynieniem 1 wdzięcznością, jest poniekąd zespoleniem sa-

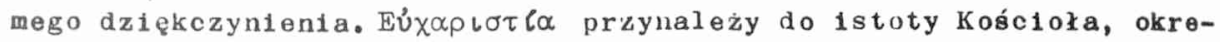
ślając jego postawę 1 związek z Chrystusem.

Ks. Franciszek Drączkowski - Lublin

DEF BEGIIFF "EUCHAIISTIE" IN DEN SCHRIFTEN DES CLEMENS VON ALEXANDRIA

/Zusamenfassung/

Der Begriff "Eucharistie" tritt 21 mal in den Schriften des Clemens von Alexandria auf. Generall kann man zwei Bedeutungsgruppen unterscheiden: 1. Der Begriff "Eucharistie" bedeutet die euchar1stische Nahrung, d.h. den Leib und das Blut Christi, sowie das Opfer des Neuen Bundes, dessen Figur das upfer Melchisedeks ist. In dieser Bedeutung tritt der Begriff bei clemens nur 4 mal aup. 2. Der Begriff "Eucharistie" bedeutet das Dankgebat, die dauernde Haltung der Danksagung, der Dankbarkeit Gott gegenuber, die den Nacisten gegenUber freunuliche art. In dieser Bedeutung tritt der Begriff in Clemens' Schriften 17 mal auf. An die Briefe des paulus ankntplend / $\mathrm{Tim}$ 4, 1-4; R8m 14, 6/, benutzt Clemens das Substantiv "eucharistia" vor allem zur Bezeichnung einer standigen Dankbarkeitshaltung, verstanden als dauernde psychische Disposition, die in der Danksagung fur alle geistigen und materiellen Guter und fur alle Ereignisse des ganzen Lebens zum Ausdruck kommen sollte. Got danken soll man zu jeder Tages- und Nachtzeit, in jeder Situation, die Momente des Kreuzes und Leidens nicht ausgeschlossen. Die Frucht einer solchen Haltung ist die Freude. Das Ideal einer so verstandenen Danksagungshaltung realisiert der wirkliche Gnostiker, d.h. der Freund Gottes, vollkommen. Der Begriff "Lucharistie" kommt bei Clemens auch in der Bedeutung des Dankgebets vor, das von ihm ausdrtlcklich als eine besondere "Gebetsart' bezeichnet wird.

Als synthetische Fassung der besprochenen Problematik wird festgestellt, dass die "Eucharistie" ein Bestandteil der Kirche ist. Im Clemens' Sicht sind identisch miteinander: der in den Herzen aller Glaubigen gegenwartige eucharistische Christus mit Christus als dem Haupt des mystischen Leibes; die Kirche als die Vereinigung der Glaugigen, die in standiger Danksagung und Dankbarkeit leben, ist gleichsam eine Vereinigung der Danksagung selbst. Die "Eucharistie" gehbrt zum Wesen der Kirche, indem sie deren faltung und Verbindung mit Christus bestimmt. 